\title{
Stochastic model on the mobility of petroleum in the soils of the Ecuadorian Amazon
}

\author{
Marco G. Heredia Rengifo ${ }^{a b c}$, Maria de Decker ${ }^{b}$, Valeria Villalta ${ }^{a}$, Mayra Vargas ${ }^{a}$, \\ ${ }^{a}$ Departamento de Ciencias de la Vida, Carrera de Ingeniería Ambiental, Universidad Estatal Amazónica (Ecuador). \\ ${ }^{b}$ Profesor en el Departamento de Ciencias de la Vida, Carrera de Ingeniería Ambiental, Universidad Estatal Amazónica (Ecuador). \\ ${ }^{c}$ Doctorando del Programa de Posgrado en Tecnologías Agroambientales para una Agricultura Sostenible, Departamento de Producción \\ Vegetal: Fitotecnia, CEIGRAM, itdUPM, Universidad Politécnica de Madrid (España).
}

mheredia@uea.edu.ec, mdedecker@uea.edu.ec, amb20140368@uea.edu.ec,amb20140352@uea.edu.ec

\begin{abstract}
The Ecuadorian Amazon has an area of 1,23 x $10^{7} \mathrm{ha}$, due to its mega biodiversity and its distribution is classified as a hot spot in the world. The overlap in its territory by oil activities, protected areas, ancestral territories and intangible zones generates a series of environmental conflicts. The oil spills have generated negative impacts on the soil, plants and animals, promoting an increase in the quality of the soils in the region. The objective of this study was to evaluate the oil contamination process in soils of the Northern Region of the Ecuadorian Amazon. Netlogo 3D software version 5.2.1 was used to simulate the evolution during 24 hours of oil percolation. The simulation scenarios were recorded according to the porosity $(\%)$ of the soils of the Northern Region of the Ecuadorian Amazon. The temporal evolution of the occupation of the soil by the oil particles is conditioned by the variables: texture, dynamic pressure, volume, gravity, vegetation cover. The dynamics of oil percolation in the simulations is directly proportional to the existence of porous spaces in the Ecuadorian Amazonian soil. The understanding of this phenomenon allows to define strategies of prevention and to mitigate the potential risks for the ecosystems.
\end{abstract}

Keywords - Hydrocarbon, behavior, scenario, percolation, saturation.

\section{INTRODUCTION}

The Ecuadorian Amazon Region (EAR) has an area of $131,137 \mathrm{~km}^{2}$, which is about 50 percent of the total area of the country [1] and 739,814 inhabitants [2].

The EAR hosts 25 ecosystems, its tropical rainforest is considered one of the world's hotspots with a record in biodiversity richness, it houses $80 \%$ of the country's biodiversity, containing the largest forest mass in the country [1]. The edaphic cover of the EAR are mostly Ultisols soils (red clay soils of periandine hills) and loamy soils [3]. Ultisols are old soils with jungle canopy in a very rainy climate, which has washed for millions of years some of the minerals it contains and thus its fertility is low [4]. Clay soils are more resistant to percolation [3] because they have a layer of 5 to 10 centimeters thin organic soil, followed by a 2 to 3 meters thick layer of clay that prevent percolation (infiltration), iron as oxide or hydroxide influences the color [4]. In the areas of watercourses, sandy soil predominates with less resistance to percolation [3].

Oil exploration in the EAR began in the 1950s, heavy crude oil deposits were identified in the central southern Amazon region (Pastaza, Napo, Morona Santiago provinces). In the north area (Sucumbíos and Orellana provinces) light oil of very good quality was found [5]. Petroleum is a complex and heterogeneous mixture of aliphatic, alicyclic and aromatic hydrocarbons having between one and sixty carbon atoms, contains oxygen, nitrogen and sulfur in changing proportions, is considered as a pollutant because of its complex chemical composition, characterized by being persistent and its ability to bioaccumulate [6]. Oil can be classified based on its density, which is measured on a scale developed by the American Petroleum Institute (API) known as API grades [7]. At one end, it is a pale, mobile, straw-colored liquid with a density between 30 and $40^{\circ}$ API (called light crude). At the other extreme, it is a highly viscous, semi-solid black substance with a density of about 10 to $22^{\circ}$ API and is considered heavy. The lower molecular weight components of the petroleum possess moderate to high solubility in water or soil, while the higher molecular weight fractions tend to form emulsions in water. The lighter aliphatic and aromatic components of the petroleum will have great mobility in the soils, while the heavier molecular weight components will have little mobility [8].

The oil activity is one of the industries with the highest environmental impacts generated locally and globally. in Ecuador, Orellana and Sucumbíos provinces have been the places of greatest impact and socio-environmental conflicts, generated by hydrocarbon sector [9].

The Ecuadorian government has divided $65 \%$ of the Amazonian territory $\left(5.23 \times 10^{6}\right.$ ha) into blocks for oil activities [10] (Figure 1). 
The Texaco (Chevron) case began exploring the oil fields in the north of the EAR in 1964. Between 1972 and 1992 it extracted 1.5 billion barrels of oil; during the process the company poured 18 billion gallons of toxic waste and 17 million gallons of crude into the environment, being one of the worst cases of oil pollution in the world [11].

In the Ecuadorian Amazon, the most severe contamination occurs due to the extraction and handling of the oil. Hydrocarbon contamination is a problem that seriously affects soils and the magnitude depends on the contaminated area, hydrocarbon concentrations, soil type, pollutant infiltration velocity as in the case of a study in the Auca field belonging to Puerto Francisco de Orellana, Orellana Province, which determined the velocity of oil infiltration in clayey soil with a velocity of $0.012 \mathrm{~m} / \mathrm{s}$. [12]. The aim of the study was to evaluate the polluting process of oil in soils of the Northern Region of the Ecuadorian Amazon.

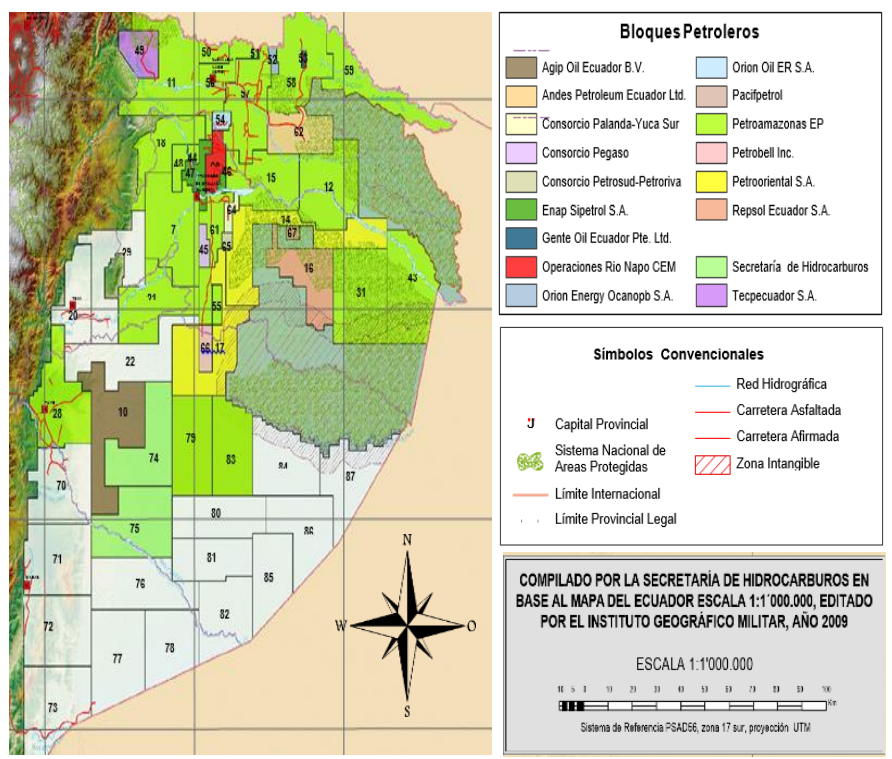

\section{MATERIALS Y METHODS}

To evaluate the polluting process by hydrocarbons (petroleum) in soils of the Northern Region of the Ecuadorian Amazon, a dynamic stochastic simulation model has been developed to weight oil percolation and soil saturation. The free software Netlogo 3D version 5.2.1 was used [14].

NetLogo is a programming environment that allows the dynamic and spatial simulation of natural and social phenomena over time. The simulation volume was $2 \mathrm{~m}^{3}$ and a percolation area of $1 \mathrm{~m}^{2}$. Four scenarios were simulated according to the porosity (\%) in the soils of the EAR: 1) $7.81 \%$ (Lago Agrio / Sucumbios); 2) $13.5 \%$ (Dayuma / Orellana); $31.36 \%$ (Joya de los Sachas / Orellana); 39.12\% (Lago Agrio / Sucumbios) [12]. The values of the model parameters were kept constant throughout the simulation process: texture, dynamic pressure, volume, gravity, vegetation cover and crude density between 30 and $40^{\circ}$ API (Table 1).

The spatial model contains 1,849 pixels equivalent to 0.54 $\mathrm{cm}^{3}$ each pixel. The random spatial distribution of oil through the soil is diagonally downward: northeast, southeast, northwest or southwest.

The scenarios were based on the real conditions (parameters) that present the soils of the Northern Region of the Amazon including the gravity, vegetation cover and density of the crude. The results of the model were considered from the average of 10 repetitions per scenario. The unit of time considered in the model is 24 hours and the simulation time is seconds.

Figure 1. Spatial distribution of the oil blocks of the Ecuadorian Amazon Region [13]

Table 1. Simulation scenarios of the oil polluting the Northern Region of the Ecuadorian Amazon

\begin{tabular}{lccccccc}
\hline Scenarios & $\begin{array}{c}\text { Porosity } \\
(\boldsymbol{\%})\end{array}$ & Texture & $\begin{array}{c}\text { Dynamic } \\
\text { pressure } \\
\text { Pascals (Pa) }\end{array}$ & $\begin{array}{c}\text { Volume } \\
(\mathbf{L})\end{array}$ & $\begin{array}{c}\text { Gravity } \\
\left(\mathbf{m} / \mathbf{s}^{\mathbf{2}}\right)\end{array}$ & $\begin{array}{c}\text { Vegetation } \\
\text { cover (\%) }\end{array}$ & $\begin{array}{c}\text { Crude } \\
\text { density } \\
(\mathbf{A P I} \text { in } \\
\left.{ }^{\circ}\right)\end{array}$ \\
\hline Perpe_1 & 7,81 & Rocky & 5,2 & 64 & 9,81 & 100 & $30-40$ \\
Perpe_2 & 13,5 & Ac -1 & 5,2 & 64 & 9,81 & 100 & $30-40$ \\
Perpe_3 & 31,36 & 1-Ar. & 5,2 & 64 & 9,81 & 100 & $30-40$ \\
Perpe_4 & 39,12 & Ar - Ar & 5,2 & 64 & 9,81 & 100 & $30-40$ \\
\hline
\end{tabular}




\section{RESULTS AND DISCUSSION}

The Stochastic model on the mobility of petroleum (Perpoil) in the soils of the Ecuadorian Amazon uses liters as unit of measure: the Perpe_1 scenario shows that at the end of the five seconds of simulation, 0.4 petroleum particles were percolated (Table 2), in the Perpe_2 scenario the oil after 10 and 15 seconds percolated a particle. At 20 seconds of simulation in the Perpe_3 and 4 scenario there is a percolation of 441.5 and 403.3 petroleum particles, respectively, showing a difference of particles between scenarios of 38.2 .

In the Perpe_1 scenario at 5 seconds, 556.17 soil units were saturated with a percolation of 0.4 petroleum particles, at 10 , 15 and 20 seconds there were no percolated particles. In the Perpe_ 2 scenario, 810.75 were saturated and 811 soil units in 10 and 15 seconds (Table 3).

The saturation difference of the soil units in the Perpe_2 and 3 scenarios is $1,004.7$ at 5 seconds. In soil with porosities of $31.36 \%$ (Perpe_3) and 39.12\% (Perpe_4), 7.303.1 and 7.621.2 soil units were saturated at 20 seconds with 441.5 and 403.3 petroleum particles respectively (Table 3 ).

Table 2. Projection of oil percolation starting from an initial volume $(64 \mathrm{~L} / \mathrm{sec})$ in the soils of the Ecuadorian Amazonian Region (unit of measurement in seconds)

Units of Time (sec)

\begin{tabular}{lrcrc}
\hline Scenario & $\mathbf{5}$ & $\mathbf{1 0}$ & $\mathbf{1 5}$ & $\mathbf{2 0}$ \\
\hline Perpe_1 & 0,4 & - & - & - \\
Perpe_2 & 10,3 & 1 & 1 & - \\
Perpe_3 & 334,5 & 340,4 & 388,5 & 441,5 \\
Perpe_4 & 378,3 & 358,1 & 372,8 & 403,3 \\
\hline
\end{tabular}

The average of the simulations in the scenarios has a linear upward trend in units of saturated soil (Figure 2A). By porosity effects in the scenarios (A) there is a similarity in the units of saturated soil with different number of percolated oil particles (B).

The temporal trend in the Perpe_1 and 2 scenarios is decreasing in the simulations of the number of percolated petroleum particles (B) while there is a two-way polynomial trend in the Perpe_ 3 and 4 scenarios.
The simulations of the expansion of an oil flow made with the Perpoil model depend on the soil thickness and porosity, parameters considered in the modeling performed with the digital elevation model (DEM) with an altimetric resolution in decimeters (10-meter pixels) [15].

Table 3. Projection of the soil saturation (units) as a function of the simulation time in the soils of the Ecuadorian Amazon Region

\section{Units of Time (sec)}

\begin{tabular}{ccccc}
\hline Scenario & $\mathbf{5}$ & $\mathbf{1 0}$ & $\mathbf{1 5}$ & $\mathbf{2 0}$ \\
\hline Perpe_1 & 556.17 & - & - & - \\
Perpe_2 & 778.9 & 810.75 & 811 & - \\
Perpe_3 & 1783.6 & 3463.90 & 5261.3 & 7303.1
\end{tabular}

Figure 2. Temporal series of stochastic modeling: A) Saturated soil units and B) Oil particles percolation in soils of the Ecuadorian Amazon Region

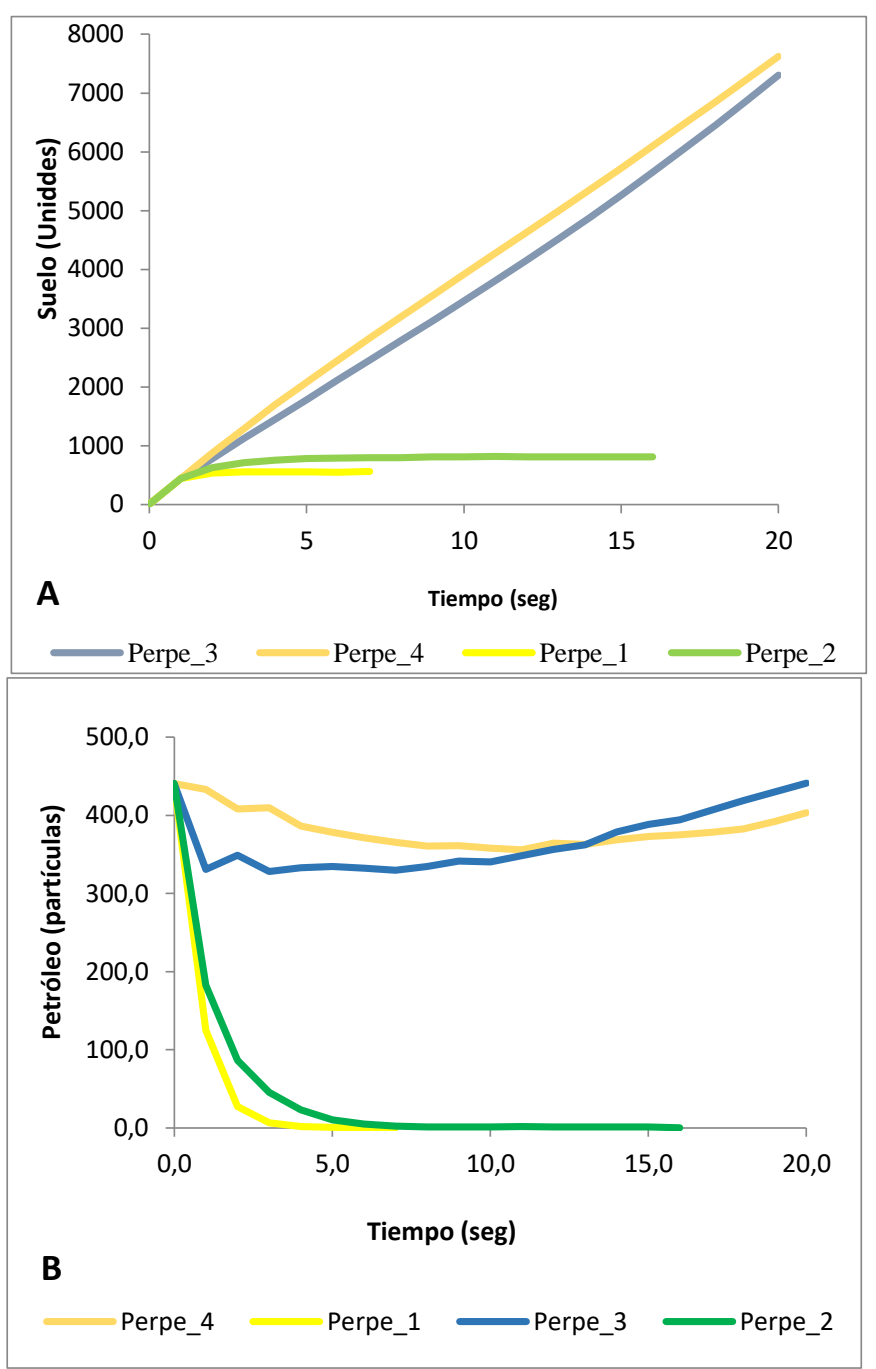




\section{CONCLUSIONS}

The percolation of the simulated petroleum particles in soils of the Northern Region of the Ecuadorian Amazon is influenced by the porosity, texture, dynamic pressure, volume, gravity and vegetation cover; the difference in the percentage of porous space in soils defines the dynamics of hydrocarbon flow.

The Perpoil model is a powerful tool that allows to evaluate the behavior of possible oil spills and to prevent their potential risks. It is recommended to fine tune and calibrate the model using parameters such as slope, viscosity, soil moisture, etc.

\section{REFERENCES}

[1] Instituto Nacional Autónomo de Investigaciones Agropecuarias, Quito (Ecuador). Estación Experimental Napo-Payamino. (2007). Contribuciones del INIAP a la Región amazónica ecuatoriana.

[2] INEC (2010).

Disponible en http://sni.gob.ec/proyecciones-y-estudios-demograficos

[3] Custode, E., \& Sourdat, M. (1986). Paisajes y suelos de la Amazonía ecuatoriana: entre la conservación y la explotación. Cultura, 24, 325-337.

[4] Ossa, O. J. (2017). Preparación del suelo, técnica necesaria para sembrar pimienta (Piper nigrum) en la Amazonia Colombiana. Revista del Sistema de Ciencia Tecnología e Innovación (SENNOVA), 2(1), 84-97.

[5] Vogliano, S. Extracción petrolera en la Amazonia. Obtenido de conflictos socioecológicos [actualizado 10 de 05 de 2010 acceso 16 de Marzo de 2016]. Disponible en: http://www.fuhem.es/media/e cosocial/image/cultur ambiente/fichas/ECUADOR_combustibles_n22.pdf

[6] Aldás Vargas, A. B. (2014). Biorremedación de suelos contaminados con hidrocarburos a escala de laboratorio (Bachelor's thesis, Quito, 2014).

[7] Clark, H. A., \& Jurs, P. C. (1979). Classification of crude oil gas chromatograms by pattern recognition techniques. Anal. Chem.;(United States), 51(6).

[8] US EPA. (2011). Hazard Characterization Document Crude oil.

[9] Fontaine, G. (Ed.). (2004). Petróleo y desarrollo sostenible en Ecuador: las apuestas (Vol. 2). FlacsoSede Ecuador.
[10] Virgen, A. A. T., \& Biodiversidad, Y. P. I. (2008). Los proyectos petroleros y gasíferos en la Amazonía occidental. Disponible en: http://www.westernamazon.org/PLoSONESAF_ONLINE-ESPANOL.pdf

[11] Serrano Narváez, H. (2013). Caso Chevron-Texaco: cuando los pueblos toman la palabra. Disponible en: http://repositorionew.uasb.edu.ec/handle/10644/4023

[12] Larrea, M. (2003). PROYECTO "AMBIODUCTO" Proyecto de investigación científica del King's College London (UNIVERSIDAD DE LONDRES) y PETROPRODUCCION y con apoyo del Concejo Británico. Disponible en: http://www.ambiotek.com/herb/ecuador/ambioducto/am bioducto.pdf

[13] Asociacion de la Industria Hidrocarburifera del Ecuador (AHIE). Mapa de bloques petroleros del Ecuador. [actualizada 4 de Febrero de 2012 acceso 15 de Marzo de 2016 Disponible en: http://www.aihe.org.ec/index.php?option=com_docman \&task=cat_view\&gid=94\&Itemid=

[14] Wilensky, U., \& Evanston, I. (1999). NetLogo: Center for connected learning and computer-based modeling. Northwestern University, Evanston, IL, 4952. Disponible en. http://ccl.northwestern.edu/netlogo

[15] Cram, S., François, J., Sommer, I., Oropeza, O., Ortiz, A., Sánchez, T., Quintero, A. (2009). Modelación del comportamiento ambiental de derrames de hidrocarburos en sitios. Instituto Nacional de Ecologia, Mexico. 